\title{
HUBUNGAN KEJADIAN BAYI BERAT LAHIR RENDAH DENGAN RIWAYAT IBU HAMIL KEKURANGAN ENERGI KRONIS DI WILAYAH PUSKESMAS PANTOLOAN
}

\author{
Widya Pani ${ }^{1 \mathrm{~K}}$ \\ ${ }^{1}$ Prodi DIII Jurusan Kebidanan Poltekkes Kemenkes Palu \\ email Penulis Korespondensi $\left({ }^{\mathrm{K}}\right)$ : widyapani.wp@gmail.com
}

\begin{abstract}
One that affects fetal growth is the nutrition of pregnant women because during pregnancy the mother must meet the rapid growth needs of the fetus, and so that the output of the pregnancy is successful and perfect. But until now there are still many pregnant women who experience nutritional problems, especially malnutrition, such as Chronic Energy Deficiency (SEZ). The number of pregnant women experiencing SEZs in the Pantoloan Community Health Center Working Area in 2016 was a total of 67 pregnant women who delivered 8 LBWs. The purpose of this study was to determine the relationship of the incidence of low birth weight babies with a history of chronic energy-deficient pregnant women in the work area of Pantoloan Health Center. This research is an Analytical type with Cros Sectional research design with a population of 252 babies born in 2010 in the Work Area of Pantoloan Health Center. Sampling uses the Total Sampling technique. The criteria for the sample are taken if you have birth weight and maternal LILA data during pregnancy, if the data is incomplete, it is not sampled. Samples that meet the requirements are 52 babies. The results showed that pregnant women who experienced SEZ 32 people $(61.5 \%)$, and LBW as many as 8 babies $(15.4 \%)$. There was a significant relationship between the incidence of LBW and a history of SEZ pregnant women ( $p$ $=0.0017)$. The conclusion, that the better the nutritional status of pregnant women during pregnancy, the better the weight of the baby will be born. It is recommended for Pantoloan Health Center to improve health education programs about nutrition, and take LILA measurements regularly for pregnant women.
\end{abstract}

Keywords: LBW, SEZ, Pregnant Women

\section{PENDAHULUAN}

\section{Latar Belakang}

Wanita, terutama wanita usia subur (WUS), bayi dan anak balita adalah kelompok usia rawan pada penduduk yang selalu harus menjadi perhatian. Masih tingginya prevalensi gizi kurang pada anak balita berhubungan dengan faktor banyaknya bayi berat lahir rendah (BBLR) ${ }^{(1)}$. BBLR merupakan salah satu faktor risiko yang mempunyai kontribusi terhadap kematian bayi khususnya pada masa perinatal. Selain itu BBLR dapat memberikan dampak jangka panjang terhadap kehidupannya dimasa depan seperti mengalami gangguan mental dan fisik pada usia tumbuh kembang selanjutnya sehingga membutuhkan biaya perawatan yang tinggi ${ }^{(1)}$.

KEK adalah keadaan dimana ibu menderita keadaan kekurangan makanan yang berlangsung menahun (kronis) yang mengakibatkan timbulnya gangguan kesehatan pada ibu, dan beratnya beban kerja ibu hamil. Ibu hamil yang menderita KEK akan mempunyai risiko 
kesakitan yang lebih besar terutama pada trimester III kehamilan dibandingkan dengan ibu hamil yang normal. Akibatnya ibu hamil mempunyai risiko lebih besar untuk melahirkan BBLR dibandingkan ibu hamil yang tidak menderita KEK ${ }^{(2)}$.

Prevalensi global BBLR adalah 15,5\%, yang berarti bahwa sekitar 20,6 juta bayi lahir hidup dengan kasus tersebut lahir setiap tahunnya, 96,5\% diantaranya di negara berkembang. Ada variasi signifikan pada kasus BBLR di tingkat wilayah PBB, dengan insiden tertinggi di Asia Selatan-Asia Tengah (27,1\%) dan terendah di Eropa (6,4\%). Secara nasional, prevalensi Kekurangan Energi Kronis (KEK) wanita hamil umur 15-49 tahun sebanyak 24,2\%. Sedangkan untuk prevalensi BBLR 10,2\% ${ }^{(3)}$.

Berdasarkan hasil penelitian Hanifah. 2009(4) dengan judul penelitian Hubungan Antara Status Gizi Ibu Hamil Dengan Berat badan Bayi Lahir di RB Pokasi, yang ingin mengetahui hubungan antara status gizi ibu hamil berdasarkan indikator Lingkar Lengan Atas (LILA) dengan bayi berat lahir. Hasil penelitian menunjukkan bahwa terdapat hubungan yang signifikan, maka kesimpulan yang dapat diambil pada penelitian Hanifah ini adalah semakin baik LILA semakin baik pula berat badan bayi lahir sedangkan semakin kurang LILA semakin kurang pula berat badan bayi lahir.

Status gizi ibu hamil dapat diukur dengan indikator pengukuran Lingkar Lengan Atas (LILA). Ambang batas LILA dengan risiko Kekurangan Energi Kronik (KEK) di Indonesia adalah $23,5 \mathrm{~cm}$. Apabila ukuran LILA kurang dari $23,5 \mathrm{~cm}$ atau dibagian pita merah LILA, artinya ibu hamil tersebut mempunyai resiko KEK. Ambang batas ini sudah digunakan di Indonesia untuk menjaring ibu hamil yang berisiko melahirkan Bayi Berat Lahi Rendah (BBLR).Dibandingkan dengan antropometri lainnya paling praktis penggunaannya di lapangan, dan oleh sebab itu beberapa penelitian merekomendasikan LILA sebagai salah satu metode untuk dapat mengetahui status gizi ibu hamil (5).

Menurut data dari hasil Riset Kesehatan Dasar tahun $2013^{(3)}$, persentase Kekurangan Energi Kronis (KEK) terendah di Bali $(10,1 \%)$ dan tertinggi di Nusa Tenggara Timur $(45,5 \%)$, sedangkan persentase BBLR terendah di Sumatera Utara $(7,2 \%)$ dan tertinggi di Sulawesi Tengah (16,9\%).

Di Kota Palu Persentase keseluruhan ibu hamil tahun 2016 sebanyak 7.935 ibu hamil terdapat 837 ibu hamil Kekurangan Energi Kornis (KEK) atau sebesar 10,55\%, Sedangkan untuk persentase BBLR di Kota Palu sebesar 3,2\% ${ }^{(6)}$.

Pada tahun 2016 jumlah ibu hamil di wilayah kerja Puskesmas Pantoloan sebanyak 315 ibu hamil. Ibu hamil yang memiliki Lingkar Lengan Atas (LILA) $<23,5 \mathrm{~cm}$ sebanyak 68 ibu hamil dan yang melahirkan dengan keadaan BBLR yaitu sebanyak 10 bayi, Sedangkan untuk total persalinan sebanyak 265 persalinan yang sudah terjadi di Puskesmas Pantoloan. Total kelahiran hidup neonatus berjumlah 266 bayi dengan kasus BBLR terdapat 16 bayi atau sebesar 6,01\%. Data ini menunjukkan bahwa kasus BBLR masih merupakan kasus tertinggi yang terjadi di wilayah kerja Puskesmas Pantoloan.

Menurut data laporan Puskesmas tahun 2016 ${ }^{(7)}$ jumlah ibu hamil di wilayah kerja Puskesmas Pantoloan sebanyak 290 ibu hamil yang memiliki ukuran LILA $<23,5 \mathrm{~cm}$ sebanyak 67 ibu hamil yang melahirkan BBLR sebanyak 8 bayi, untuk total persalinan sebanyak 251 persalinan. Sedangkan total kelahiran hidup neonatus berjumlah 252 bayi dengan kasus BBLR sebesar 23 bayi atau sebesar 9,12\%.

\section{Tujuan}

Tujuan penelitian untuk mengetahui hubungan kejadian BBLR dengan riwayat ibu hamil dengan kekurangan kalori energi.

22 | Penerbit: Jurusan Kebidanan, Poltekkes Kemenkes Palu 


\section{METODE PENELITIAN}

Jenis penelitian adalah analitik menggunakan pendekatan "cross sectional"di mana dalam kegiatan penelitian ini ingin mengetahui hubungan variabel independen dan variabel dependen ${ }^{(8)}$, yang menjadi variabel independen adalah kejadian BBLR dan varabel dependen adalah riwayat ibu hamil dengan kekurangan kalori energi. Penelitian dilaksanakan di Wilayah Kerja Puskesmas Pantoloan pada tanggal 6 sampai dengan 11 Agustus tahun 2017. Populasi pada penelitian ini adalah seluruh bayi yang lahir hidup pada bulan Januari sampai dengan Juli 2017, yaitu berjumlah 252 bayi di Wilayah Kerja Puskesmas Pantoloan. Sampel dalam penelitian ini adalah seluruh bayi yang lahir pada bulan Januari sampai dengan Juli 2017 yang tercatat di rekam medik. Adapun kriteria sampel diambil yaitu jika memiliki data berat lahir dan LILA ibu pada saat hamil, jika data tidak lengkap maka tidak dijadikan sampel. Jumlah sampel yang memenuhi syarat adalah 52 orang dengan teknik pengambilan sampel menggunakan teknik total populasi, yaitu teknik penentuan sampel dengan mengambil seluruh anggota populasi sebagai responden atau sampel.

\section{HASIL PENELITIAN}

Berdasarkan analisis univariat maka hasil penelitian menggambarkan distribusi frekuensi dan proporsi masing-masing variabel yang diteliti, baik variabel independent maupun dependen yaitu Bayi Berat Lahir Rendah dan Ibu Hamil dengan Lingkar Lengan Atas (LILA) yang dapat dilihat pada tabel berikut ini:

Tabel 1

Distribusi Bayi Berat Lahir Rendah Di Wilayah Kerja Puskesmas Pantoloan Tahun 2017

\begin{tabular}{llcc}
\hline No & \multicolumn{1}{c}{ Bayi Berat Lahir } & f & $\%$ \\
\hline 1 & BBLR & 8 & 15,4 \\
2 & Tidak BBLR & 44 & 86,4 \\
\hline & Total & 52 & 100 \\
\hline
\end{tabular}

Berdasarkan tabel 1 menunjukkan bahwa dari 52 responden terdapat 8 bayi $(15,4 \%)$ yang lahir $<2500$ gr, dan 44 bayi $(84,6 \%)$ yang lahir $\geq 2500$ gr.

Tabel 2.

Distribusi Berdasarkan Ibu Hamil Dengan Lingkar Lengan Atas (LILA) di Wilayah Kerja Puskesmas Pantoloan Tahun 2017

\begin{tabular}{lcc}
\hline Lingkar Lengan Atas (LILA) $(\mathrm{cm})$ & $\mathrm{f}$ & $\%$ \\
\hline KEK & 32 & 61,5 \\
Tidak KEK & 20 & 38,5 \\
\hline Total & 52 & 100,0 \\
\hline
\end{tabular}

23 | Penerbit: Jurusan Kebidanan, Poltekkes Kemenkes Palu 
Berdasarkan tabel 2 menunjukkan bahwa dari diketahui bahwa dari 52 ibu yang melahirkan terdapat 32 orang (61,5\%) menderita Kurang Energi Kronis (KEK) pada saat hamil, dan terdapat 20 orang $(38,5 \%)$ yang tidak menderita KEK pada saat hamil

Berdasarkan analisis bivariat menggambarkan hubungan antara masing-masing variabel, baik variabel independent yaitu Bayi Berat Lahir Rendah maupun variabel dependent yaitu riwayat ibu hamil Kekurangan Energi Kronis. Penelitian ini menggunakan uji chi square, dengan pemaknaan 0,05 dan kepercayaan 95\%. Namun, untuk tabel $2 \times 2$ yang memiliki sel dengan nilai expected count $<5$ maka menggunakan uji fisher's exact.

Tabel 3.

Hubungan Bayi Berat Lahir Rendah dan Riwayat Ibu Hamil Kekurangan Energi Kronis di Wilayah Kerja Puskesmas Pantoloan

\begin{tabular}{cccccccc}
\hline & \multicolumn{4}{c}{ KEK } & \multicolumn{2}{c}{ TOTAL } & \multirow{2}{*}{ P value } \\
\cline { 2 - 7 } BBLR & \multicolumn{2}{c}{ YA } & \multicolumn{3}{c}{ TIDAK } & & \\
\cline { 2 - 7 } & $\mathrm{n}$ & $\%$ & $\mathrm{n}$ & $\%$ & $\mathrm{n}$ & $\%$ & \\
\hline YA & 8 & 100 & 0 & 0 & 8 & 100 & 0,017 \\
TIDAK & 24 & 54,5 & 20 & 45,5 & 44 & 100 & \\
\hline
\end{tabular}

Berdasarkan tabel 3 hasil menunjukkan bahwa ibu hamil dengan riwayat mengalami KEK dan melahirkan anak BBLR 8 bayi (100\%), ibu hamil yang mengalami KEK dan melahirkan anak tidak BBLR 24 bayi (54,5\%), ibu hamil yang tidak mengalami KEK dan melahirkan anak BBLR 0 bayi $(0 \%)$, ibu hamil yang tidak mengalami KEK dan melahirkan anak tidak BBLR 20 bayi (45,5\%).

Berdasarkan perhitungan nilai expected count setiap kolom yang telah dilakukan, didapatkan lebih dari $20 \%$ kolom yang memiliki nilai expected count $<5$, karena penelitian ini menggunakan tabel $2 \times 2$ sehingga uji fisher's exact di pilih sebagai uji statistik yang digunakan. Dari hasil uji fisher's exact didapatkan nilai $\mathrm{p}=0,017$ ( $\mathrm{p}$. value $<0,05$ ) dalam uji statistik apabila $\mathrm{p}<0,05$ menunjukkan bahwa Ho ditolak, berarti ada hubungan yang bermakna antara kejadian bayi berat lahir rendah dengan riwayat ibu hamil kekurangan energi kronis.

\section{PEMBAHASAN}

Hasil penelitian ini secara statistik didapatkan hubungan secara siginifikan, yaitu ada hubungan yang bermakna antara kejadian bayi berat lahir rendah dengan riwayat ibu hamil kekurangan energi kronis, karena asupan seorang ibu yang sedang dalam masa kehamilan merupakan hal yang sangat penting. Tumbuh kembang anak sangat ditentukan kondisinya saat masa janin dalam kandungan. Apabila asupan kebutuhan gizi ibu hamil kurang maka akan berdampak pula bagi bayi nantinya.

Hal ini sejalan dengan hasil penelitian Trihardiani. 2009(9), ada beberapa faktor yang mempengaruhi bayi dapat lahir dengan berat lahir rendah seperti umur ibu, umur kehamilan, paritas, dan penyakit infeksi. Hal ini dikarenakan umur ibu hamil yang belum cukup untuk dapat hamil di usia yang masih remaja, kebutuhan gizi remaja relatif besar karena masih mengalami pertumbuhan dan membutuhkan energi yang cukup untuk dirinya sendiri, dan semakin muda umur kehamilan kelahiran dapat berdampak pada berat lahir bayi dikarenakan ketidak seimbangan antara asupan makanan yang berkaitan pula dengan penyakit infeksi, kekurangan asupan makanan membuat daya tahan tubuh sangat lemah, memudahkan terkena penyakit infeksi karena sanitasi lingkungan yang buruk, sehingga ibu menjadi kurang gizi dan berdampak pada bayi. 
Kondisi Kekurangan Energi Kronis (KEK) dapat terjadi pada wanita usia subur dan pada ibu hamil, Hal ini menggambarkan keadaan dimana ibu menderita kekurangan makanan berlangsung menahun ${ }^{(2)}$. Menurut hasil penelitian Hidayati, dkk. $2005^{(10)}$ di Kota Mataram yang mengatakan ibu hamil yang terpapar KEK memiliki probabilitas lebih tinggi untuk melahirkan BBLR dibandingkan yang tidak terpapar KEK, status gizi yang kurang baik sebelum atau selama hamil cenderung menyebabkan ibu melahirkan BBLR. Sejalan juga dengan penelitian yang dilakukan oleh Hanifah, 2009(4) di RB Pokasi yang mengatakan semakin baik LILA semakin baik pula berat badan bayi lahir sedangkan semakin kurang LILA semakin kurang pula berat badan bayi lahir.

Menurut hasil penelitian Pratiwi. 2008(11), Berat badan lahir bayi dipengaruhi juga oleh beberapa hal yaitu status Kekurangan Energi Kronis (KEK) dan anemia pada ibu hamil. Status KEK dipengaruhi oleh tingkat konsumsi ibu dan faktor infeksi dimana ketika ibu kekurangan asupan energi dalam jangka waktu yang lama maka ibu akan menderita KEK, karena ibu yang menderita KEK pada saat kehamilan mempunyai risiko melahirkan BBLR 5 kali lebih tinggi dibandingkan dengan ibu dengan status gizi baik.

Ditinjau dari hasil bahwa ada ibu hamil yang mengalami keadaan Kekurangan Energi Kronis (KEK) dengan kejadian tidak BBLR (75\%), kondisi ini diduga sudah ditindak lanjuti pada awal pemeriksaan kehamilan dimana ukuran LILA ibu hamil $<23,5 \mathrm{~cm}$ dengan diadakannya Pemberian Makanan Tambahan (PMT), karena di Puskesmas Pantoloan mempunyai suatu kegiatan PMT bagi ibu hamil yang KEK, sedangkan untuk ibu hamil yang mengalami keadaan KEK dengan kejadian BBLR (25\%), dimana ibu hamil yang belum mendapatkan perawatan cepat dan belum ditangani sehingga berdampak pada kesehatan ibu beserta janin dalam kandungan.

Menurut Rahayu, 2012(12), hal ini disebabkan karena kebutuhan nutrisi yang dibutuhkan oleh janin pada saat masih berada di dalam kandungan untuk masa pertumbuhan dan perkembangan janin tidak cukup, karena ibu hamil dengan ukuran LILA $<23,5 \mathrm{~cm}$ memiliki sedikit nutrisi untuk memenuhi asupan nutrisi janinnya. Untuk memperkecil risiko BBLR diperlukan upaya mempertahankan kondisi gizi yang baik pada ibu hamil. Upaya yang dilakukan berupa pengaturan konsumsi makanan, Pemberian Makanan Tambahan (PMT) bagi ibu hamil KEK, pemantauan pertambahan berat badan, pemeriksaan kadar $\mathrm{Hb}$, dan pengukuran LILA sebelum atau saat hamil.

Menurut Hidayati, F. 2009(13), ketika jumlah makanan yang dikonsumsi tidak cukup atau tidak adekuat. Hal ini menyebabkan penurunan volume darah, sehingga aliran darah ke plasenta menurun, maka ukuran plasenta berkurang dan transport zat gizi juga berkurang yang mengakibatkan pertumbuhan janin terhambat dan akan melahirkan BBLR.

Solusi yang dapat diberikan oleh peneliti dalam masalah ini adalah meningkatkan program kesehatan gizi berupa penyuluhan tentang gizi, dan melakukan pengukuran LILA secara teratur pada ibu hamil. Menghimbau masyarakat setempat untuk lebih proaktif dalam meningkatkan pengetahuan tentang kesehatan ibu dan anak terutama mengenai kesehatan ibu dan anak terutama mengenai kesehatan bayi melalui penyuluhan-penyuluhan yang dilakukan oleh tenaga-tenaga kesehatan.

\section{SIMPULAN DAN SARAN}

Berdasarkan hasil penelitian ini maka dapat disimpulkan bahwa ada hubungan yang bermakna antara kejadian bayi berat lahir rendah (BBLR) dengan riwayat ibu hamil kekurangan energi kronis (KEK). Upaya yang dapat dilakukan adalah oleh petugas kesehatan perlu digalakkannya upaya-upaya penurunan Kekurangan Energi Kronis (KEK) seperti Pemberian Makanan Tambahan (PMT) sedini mungkin, pemantauan status gizi ibu sebelum dan selama hamil perlu dilakukan lebih intensif untuk mencegah terjadinya BBLR, serta 
penyuluhan makanan sehat bagi ibu hamil, penyuluhan yang mudah dimengerti oleh ibu hamil tentang risiko yang ada pada saat kehamilan, dan di harapkan dapat mengadakan kegiatan kunjungan rumah terhadap ibu hamil yang tidak rutin ke pelayanan kesehatan, bagi pihak Puskesmas Pantoloan agar lebih meningkatkan program penyuluhan kesehatan tentang gizi, dan melakukan penguluran LILA secara teratur pada ibu hamil, serta dapat meningkatkan kerja sama denga petugas gizi yang ada di Puskesmas tersebut dalam memantau pemenuhan gizi seimbang pada ibu hamil.

\section{DAFTAR PUSTAKA}

1. Proverawati, A. \& Ismawati C. 2009. (BBLR) Berat Badan Lahir Rendah. Nuha Medika : Yogyakarta.

2. Cakrawati, D \& Mustika. 2008. Bahan Pangan, Gizi, dan Kesehatan. Alfabeta : Bandung.

3. Kementrian Kesehatan RI. 2013. Riset Kesehatan Dasar.

4. Hanifah, L. 2009. Hubungan Antara Status Gizi Ibu Hamil Dengan Berat Badan BayiLahir (Studi Kasus RB Pokasi). Karya Tulis Ilmiah. (Online), http://core.ac.uk/download/pdf/12351384.pdf

5. Supariasa I.D.N, Bakri B, Fajar I. 2002. Penilaian Status Gizi. EGC : Jakarta

6. Dinas Kesehatan Kota Palu. 2016. Profil Dinas Kesehatan 2016

7. Puskesmas Pantoloan, 2017. Laporan Bulanan Januari sampai Juli 2017

8. Notoatmodjo, Soekidjo. 2010. Metodologi Penelitian Kesehatan. Rineka Cipta : Jakarta.

9. Trihardiani, I. 2009. Faktor Risiko Kejadian Berat Badan Lahir Rendah Di Wilayah Kerja Puskesmas Singkawang Timur Dan Utara Kota Singkawang. Artikel Penelitian. (Online). http://eprints.undip.ac.id.

10. Hidayati M, Hadi H, Susilo J. 2005. Kurang Energi Kronis Dan Anemia Ibu Hamil Sebagai Faktor Risiko Kejadian Berat Bayi Lahir Rendah Di Kota Mataram Propinsi Nusa Tenggara Barat. Jurnal Kesehatan. (Online), (http://pasca.unhas.ac.id/jurnal/files/).

11. Pratiwi, A. H. 2008. Pengaruh Kekurangan Energi Kronis (KEK) Dan Anemia Saat Kehamilan Terhadap Berat Badan Lahir Rendah (BBLR) Dan Nilai APGAR. Skripsi. (Online). (http://repository.unej.ac.id).

12. Rahayu, I. P. 2012. Hubungan Ukuran Lingkar Lengan Atas (LILA) Ibu Hamil Dengan Kejadian Bayi Berat Lahir Rendah Di Wilayah Kerja Puskesmas Mabelopura Kecamatan Palu Selatan. Karya Tulis Ilmiah

13. Hidayati, F. 2009. Hubungan Antara Pola Konsumsi, Penyakit Infeksi Dan Pantang Makanan Terhadap Risiko Kurang Energi Kronis (KEK) Pada Ibu Hamil Di Puskesmas Ciputat Kota Tangerang Selatan. Skripsi. (Online). (http://repository.uinjkt.ac.id/FKIK.pdf). 